P-ISSN:

\title{
ANALISIS PREDIKSI KEBANGKRUTAN MENGGUNAKAN MODEL ALTMAN Z-SCORE PADA PT EXPRESS TRANSINDO UTAMA (TAXI), TBK
}

Anugrahwati Ariatma

Universitas Mulawarman

Email : aanugrahwati@gmail.com

DOI: doi.org// $\mathrm{xxxxx}$

Informasi Artikel

$\begin{array}{ll}\text { Tanggal Masuk } & \text { November } \\ 18^{\text {th }}, 2020\end{array}$

Tanggal Revisi November

$29^{\text {th }}, 2020$

Tanggal diterima December

$12^{\text {th }}, 2020$

Keywods:

Bankcruptcy

Altman Z-score

Financial Ratio

\section{Abstract:}

Anugrahwati Ariatma, 2020. Bankruptcy Prediction Analysis Using the Altman Z-score Model at PT Express Transindo Utama (TAXI) Tbk. This research is under the guidance of Mrs. Ferry Diyanti as a Supervising Lecturer. This study aims to determine and analyze bankruptcy predictions at PT Express Transindo Utama (TAXI) Tbk using the Altman Z-score model, whether PT Express Transindo Utama (TAXI) Tbk is experiencing symptoms of financial problems and is in the bankrupt category or is included in the non-bankrupt category based on interpretation of the Altman Z-score model. The type of data used in this research is quantitative and the data source used is secondary data. The analytical tool in this study using the Altman Z-score model. From the results of the analysis based on calculations that have been carried out on the financial statements of PT Express Transindo Utama (TAXI) Tbk in 2015 and 2016 the company is included in the gray area category because the $Z$-score shows a value of $1.1<Z<2.6$. But in 2017 and 2018 the Z-score shows a $Z$ value $<1.1$, so the company is in the bankrupt category or the company is experiencing serious financial problems. This is due to the larger current debt of the company compared to the current assets of the company as well as the less than maximum revenue earned and the large operating costs of the company. Companies can overcome this by reducing debt and increasing revenue.

Kata Kunci:

Kebangkrutan

Altman Z-score

Rasio Keuangan

\begin{abstract}
Abstrak:
Anugrahwati Ariatma, 2020. Analisis Prediksi Kebangkrutan Menggunakan Model Altman Z-score pada PT Express Transindo Utama (TAXI) Tbk. Penelitian ini dibawah bimbingan Ibu Ferry Diyanti selaku Dosen Pembimbing. Penelitian ini bertujuan untuk mengetahui dan menganalisis prediksi kebangkrutan pada PT Express Transindo Utama (TAXI) Tbk menggunakan model Altman Z-score, apakah PT Express Transindo Utama (TAXI) Tbk mengalami gejala masalah keuangan dan masuk
\end{abstract}


dalam kategori bangkrut atau masuk dalam kategori tidak bangkrut berdasarkan interpretasi model Altman Z-score. Jenis data yang digunakan dalam penelitian ini adalah kuantitatif serta sumber data yang digunakan adalah data sekunder. Alat analisis dalam penelitian ini menggunakan model Altman Z- score. Dari hasil analisis berdasarkan perhitungan yang telah dilakukan terhadap laporan keuangan PT Express Transindo Utama (TAXI) Tbk pada tahun 2015 dan 2016 perusahaan masuk dalam kategori grey area karna Z-score menunjukkan nilai $1,1<\mathrm{Z}<2,6$. Tetapi pada tahun 2017 dan 2018 Z-score menunjukkan nilai $\mathrm{Z}<1,1$ sehingga perusahaan masuk dalam kategori bangkrut atau perusahaan mengalami masalah keuangan yang sangat serius. Hal ini disebabkan karena lebih besarnya hutang lancar perusahaan dibandingkan dengan aset lancar perusahaan serta kurang maksimalnya pendapatan yang diperoleh dan besarnya biaya operasional perusahaan. Perusahaan dapat mengatasi hal ini dengan cara mengurangi hutang dan meningkatkan pendapatan.

\section{PENDAHULUAN}

Tujuan didirikannya suatu perusahaan pada umumnya adalah untuk memperoleh laba, meningkatkan penjualan, memaksimalkan nilai saham dan meningkatkan kesejahteraan pemegang saham. Untuk mencapai tujuan tersebut, perusahaan dituntut memiliki kemampuan pengelolaan yang baik agar perusahaan dapat maju dan berkembang dalam jangka waktu yang panjang dan bersaing secara kompetitif. Kemampuan perusahaan untuk dapat bertahan dan bersaing sangat ditentukan oleh kinerja perusahaan itu sendiri. Laporan keuangan adalah sumber informasi utama yang dapat digunakan untuk menilai kinerja serta tingkat kesehatan dari sebuah perusahaan, dan untuk melakukan evaluasi terkait efektivitas kebijakan yang diambil oleh pihak manajemen.

Gambaran mengenai tingkat posisi finansial terutama kesehatan perusahaan dapat menjadi bahan pertimbangan bagi pihak-pihak yang berkepentingan seperti kreditur yang akan memberikan kredit pada perusahaan serta dapat menjadi salah satu acuan bagi investor sebelum mengambil keputusan investasi. Investasi perusahaan sangat erat kaitannya dengan resiko ketidakpastian di masa mendatang. Diantara resiko yang dapat terjadi adalah dana yang telah diinvestasikan tidak kembali seperti yang diharapkan. Kemungkinan investor dan kreditur dirugikan sebab ada kemungkinan di masa depan perusahaan mengalami kondisi kesulitan keuangan (financial distress) yang mengarah pada kebangkrutan sehingga berisiko mengakibatkan perusahaan tersebut tidak dapat memenuhi kewajibannya.

Kebangkrutan diartikan sebagai kegagalan perusahaan dalam menjalankan operasi untuk mencapai misi atau tujuan perusahaan. Berdasarkan Undang Undang Nomor 4 Tahun 1998, kebangkrutan dapat didefinisikan sebagai suatu kondisi dimana sebuah entitas dinyatakan oleh keputusan pengadilan bahwa entitas bersangkutan mempunyai dua kreditur atau lebih dan tidak mampu melunasi kewajibannya paling tidak satu hutang yang telah jatuh tempo dan bisa ditagih. Resiko kebangkrutan bagi perusahaan sebenarnya dapat dilihat dan diukur melalui laporan keuangan dengan cara, melakukan analisis rasio terhadap laporan keuangan yang dikeluarkan oleh perusahaan yang bersangkutan. Analisis rasio merupakan alat yang sangat penting untuk mengetahui 
posisi keuangan perusahaan serta hasil-hasil yang telah dicapai sehubungan dengan pemilihan strategi perusahaan yang telah dilaksanakan.

Masing-masing analisis rasio keuangan memiliki kegunaan dan memberikan indikasi yang berbeda mengenai kesehatan keuangan perusahaan. Oleh karena itu, jika hanya bergantung pada perhitungan rasio secara individual maka investor akan kesulitan untuk memutuskan apakah perusahaan dalam kondisi sehat atau sebaliknya. Untuk melengkapi keterbatasan dari analisis rasio dapat dipergunakan alat analisis yang menghubungkan beberapa rasio sekaligus untuk memprediksi kebangkrutan suatu perusahaan. Alat analisis yang digunakan untuk memprediksi potensi kebangkrutan perusahaan ada berbagai macam model yaitu, model Altman Z-score, model Springate, dan model Grover.

Model Altman Z-score merupakan sebuah alat prediksi kebangkrutan yang dibuat oleh Dr. Edward I. Altman pada tahun 1968. Model ini menggunakan rasio-rasio tertentu dalam rangka memprediksi kebangkrutan sebuah perusahaan. Menurut Prihadi (2011), prediksi kebangkrutan Altman Z-score merupakan salah satu analisis fundamental yang menggunakan lima rasio keuangan seperti : Working Capital to Total Assets, Retained Earning to Total Assets, Earning Before Interest and Taxes to Total Assets, Market Value of Total Equity to Book Value of Total Debt, dan Sales to Total Assets.

Seiring dengan perkembangan zaman dan perubahan kondisi ekonomi serta perilaku pasar analisis Z-score yang pertama kali dikembangkan oleh Altman pada tahun 1968 tersebut dinilai kurang relevan dengan kekurangan antara lain dari model ini tidak dapat mutlak digunakan karena ada kalanya terdapat hasil yang berbeda jika menggunakan obyek penelitian yang berbeda. Pada tahun 1995 Altman memutuskan untuk memodifikasi formula Z-score dengan merubah beberapa indikator baru. Indikator tersebut antara lain : Net Working Capital to Total Assets, Retained Earning to Total Assets, Earning Before Interest and Taxes to Total Assets, dan Book Value of Equity to Total Liability.

Model Springate merupakan alat analisis yang penelitiannya dilakukan oleh Gordon L.V Springate pada tahun 1978 yang menghasilkan model prediksi kebangkrutan yang dibuat dengan mengikuti prosedur model Altman Z-score. Model Springate menggunakan empat rasio keuangan yang dipilih berdasarkan 19 rasio-rasio keuangan dalam berbagai literature. Empat rasio keuangan yang digunakan yaitu : Working Capital to Total Assets, Earning Before Interest and Taxes to Total Assets, Earning Before Taxes to Current Liabilities, dan Sales to Total Assets.

Model Grover merupakan model yang diciptakan dengan melakukan pendesainan dan penilaian ulang terhadap model Altman Z-score. Jeffrey S. Grover menggunakan sampel sesuai dengan model Altman Z-score pada tahun 1968 dengan menambahkan 13 rasio keuangan baru. Sampel yang digunakan sebanyak 70 perusahaan dengan 35 perusahaan bangkrut dan 35 perusahaan yang tidak bangkrut pada tahun 1982 sampai dengan tahun 1996. Rasio yang digunakan dalam model analisis ini yaitu : Working Capital to Total Assets, Earning Before Interest and Taxes to Total Assets, dan Return on Assets (ROA).

Dari ketiga model analisis prediksi kebangkrutan yang telah dijelaskan pada paragraf sebelumnya, model analisis Altman Z-score sangat efektif untuk dapat memprediksi kebangkrutan beberapa tahun sebelum terjadi kebangkrutan. Model analisis ini dapat mengkombinasikan berbagai rasio menjadi suatu model prediksi yang berarti. Analisis ini merupakan analisis multivariate yang bisa melihat hubungan rasio tertentu yang dapat mempengaruhi kinerja keuangan perusahaan. Selain itu analisis ini 
dapat digunakan untuk seluruh perusahaan, baik perusahaan publik, pribadi, manufaktur serta perusahaan jasa.

Express Group dalam dua dekade telah tumbuh menjadi salah satu perusahaan transportasi darat terkemuka di Indonesia. Secara komersial memulai kegiatan operasionalnya pada bulan April 1989 sebagai anak perusahaan Rajawali Corpora, yang merupakan salah satu operator taksi terbesar di Indonesia menyediakan layanan taksi dan layanan transportasi bernilai tambah. Perusahaan menawarkan taksi reguler, premium, dan Value Added Transport Business (VATB) yang terdiri dari layanan penyewaan premium dan layanan penyewaan bus. Express Group telah melayani basisnya di wilayah Jabodetabek dan telah berkembang untuk melayani kota-kota besar lainnya termasuk Medan, Surabaya, Semarang, Bandung, Bali dan Lombok.

Menurut laporan yang diperoleh pada laporan tahunan perusahaan, kinerja keuangan pada tahun 2015 mengalami penurunan dibandingkan dengan tahun 2014 dalam beberapa indikator finansial utama. Pada tahun 2016, kinerja keuangan perusahaan mengalami penurunan dibandingkan dengan tahun 2015. Pada tahun 2016, perusahaan mencatatkan rugi bersih yang diatribusikan kepada pemilik sebesar Rp 184 miliar dengan rugi per saham dasar sebesar Rp 85,99. Kinerja keuangan pada tahun 2017 juga mengalami penurunan dibandingkan tahun 2016. Pada tahun 2017, Grup Express mencatatkan rugi bersih yang diatribusikan kepada pemilik sebesar Rp 491 miliar dengan rugi per saham dasar sebesar Rp 229. Tinjauan keuangan pada akhir tahun 2018, jika dibandingkan dengan tahun 2017 juga mengalami penurunan di beberapa indikator finansial utama. Perusahaan pada tahun 2018 mencatatkan jumlah rugi komprehensif yang dapat diatribusikan kepada pemilik entitas induk sebesar Rp 830,7 miliar dengan rugi $\operatorname{Rp} 389,81$ per saham.

Dari uraian yang penulis kemukakan, maka penulis tertarik untuk menganalisis kebangkrutan perusahaan dengan menggunakan metode Altman Z-score dengan judul "Analisis Prediksi Kebangkrutan Menggunakan Model Altman Z-score pada PT Express Transindo Utama (TAXI) Tbk."

\section{METODE PENELITIAN}

\section{Definisi Operasional}

Definisi operasional yang terkait dalam penelitian ini adalah sebagai berikut:

1. Prediksi Kebangkrutan

Prediksi kebangkrutan adalah prediksi kegagalan PT Express Transindo Utama, tbk dalam menjalankan operasi perusahaan untuk menghasilkan laba. Resiko yang dialami oleh PT Express Transindo Utama, tbk karena ketidakmampuannya dalam memenuhi kewajiban jangka panjang dan jangka pendeknya sehingga berpengaruh terhadap terganggunya aktivitas perusahaan. Kebangkrutan merupakan akibat terburuk dari financial distress yang tidak diatasi secara tepat.

2. Model Altman Z-score

Model Altman Z-score adalah alat ukur yang digunakan untuk memprediksi kebangkrutan pada PT Express Transindo Utama, tbk, sehingga kondisi kebangkrutan dari perusahaan bisa diketahui sedini mungkin. Formula Z-score yang digunakan untuk menghitung pada PT Express Transindo Utama, tbk adalah sebagai berikut:

$$
\mathrm{Z}=6,56\left(\mathrm{X}_{1}\right)+3,26\left(\mathrm{X}_{2}\right)+6,72\left(\mathrm{X}_{3}\right)+1,05\left(\mathrm{X}_{4}\right)
$$

Rasio dari Model Altman Z-score ini adalah sebagai berikut: 
1. Working Capital to Total Assets ( $\left.\mathrm{X}_{1}\right)$

Working Capital to Total Asset atau Modal Kerja terhadap Total Aset.

$\mathrm{X}_{1}=\frac{\text { Modal Kerja }}{\text { Total Aset }}$ atau $\frac{\text { Aset Lancar-Utang Lancar }}{\text { Total Aset }}$

2. Retained Earnings to Total Assets ( $\left.\mathrm{X}_{2}\right)$

Retained Earnings to Total Assets atau Laba Ditahan terhadap Total Aset.

$\mathrm{X}_{2}=\frac{\text { Laba Ditahan }}{\text { Total Aset }}$ atau $\frac{\text { Laba Bersih-Dividen yang Dibayarkan }}{\text { Total Aset }}$

3. Earnings Before Interest and Taxes to Total Assets $\left(\mathrm{X}_{3}\right)$

Earnings Before Interest and Taxes to Total Assets atau Laba Sebelum Bunga dan Pajak terhadap Total Aset.

$\mathrm{X}_{3}=\frac{\text { Laba Sebelum Bunga dan Pajak }}{\text { Total Aset }}$

4. Book Value of Equity to Book Value of Total Debt $\left(\mathrm{X}_{4}\right)$

Book Value of Equity to Book Value of Total Debt atau Nilai Buku Ekuitas terhadap Nilai Buku Total Hutang.

$\mathrm{X}_{4}=\frac{\text { Nilai Buku Ekuitas }}{\text { Nilai Buku Total Hutang }}$

\section{Jenis dan Sumber Data}

Jenis data yang digunakan dalam penelitian ini merupakan data kuantitatif. Data kuantitatif adalah data yang berbentuk angka, misalnya: harga saham, profitabilitas, aktiva, hutang. Sumber data yang digunakan dalam penelitian ini adalah data sekunder. Data sekunder adalah data yang bersumber dari catatan yang ada pada perusahaan dan dari sumber lainnya yaitu dengan mengadakan studi kepustakaan dengan mempelajari buku-buku yang ada hubungannya dengan obyek penelitian. Sumber dari penelitian ini adalah berupa laporan keuangan tahunan dari PT Express Transindo Utama (TAXI), Tbk yang dipublikasikan. Laporan keuangan tahunan yang dipublikasikan dapat diperoleh pada situs perusahaan yaitu www.expressgroup.co.id dan pada situs Bursa Efek Indonesia yaitu www.idx.co.id

\section{Metode Pengumpulan Data}

Dalam pengumpulan data penelitian ini, penulis menggunakan metode dokumentasi. Metode dokumentasi lebih mengarah kepada bukti konkret. Dengan metode ini, penulis menganalisis dari dokumen-dokumen yang dapat mendukung penelitian.

\section{Alat Analisis Data}

Dalam penelitian ini, penulis menggunakan analisis data deskriptif yang berusaha menggambarkan berbagai karakteristik data yang berasal dari suatu sampel. Selain itu penelitian ini menggunakan analisis multivariate, yaitu analisa metode statistik yang memungkinkan melakukan penelitian terhadap lebih dari dua variabel secara bersamaan. Dalam penelitian ini, analisis multivariate yang digunakan adalah analisis prediksi kebangkrutan model Altman Z-score. Rumus dari model Altman Z-score adalah sebagai berikut:

$$
\mathrm{Z}=6,56\left(\mathrm{X}_{1}\right)+3,26\left(\mathrm{X}_{2}\right)+6,72\left(\mathrm{X}_{3}\right)+1,05\left(\mathrm{X}_{4}\right)
$$

Setelah data yang diperoleh dimasukan dalam rumus atau persamaan tersebut menghasilkan tiga kriteria sebagai berikut:

a. Jika nilai $\mathrm{Z}<1,1$ maka termasuk perusahaan yang bangkrut.

b. Jika nilai $1,1<\mathrm{Z}<2,6$ maka termasuk grey area (tidak dapat ditentukan apakah perusahaan sehat ataupun mengalami kebangkrutan.

c. Jika nilai $\mathrm{Z}>2,6$ maka termasuk perusahaan yang tidak bangkrut. 


\section{HASIL PENELITIAN}

\section{Working Capital to Total Assets ( $\left.\mathrm{X}_{1}\right)$}

Rasio ini menunjukkan kemampuan perusahaan untuk menghasilkan modal kerja bersih dari keseluruhan total aktiva yang dimiliki. Modal kerja yang negatif kemungkinan besar akan mengalami masalah dalam menutupi kewajiban jangka pendeknya karena tidak tersedianya aktiva lancar yang cukup untuk menutupi kewajiban tersebut.

\section{Working Capital}

\begin{tabular}{|c|c|c|c|}
\hline Tahun & $\begin{array}{c}\text { Current Assets } \\
\text { (Rp) }\end{array}$ & $\begin{array}{c}\text { Current Liabilities } \\
\text { (Rp) }\end{array}$ & $\begin{array}{c}\text { Working Capital } \\
\text { (Rp) }\end{array}$ \\
\hline 2015 & 618.300 .190 & 425.777 .929 & 192.522 .261 \\
\hline 2016 & 712.446 .735 & 174.571 .384 & 537.875 .351 \\
\hline 2017 & 452.880 .577 & 535.116 .207 & -82.235 .630 \\
\hline 2018 & 499.247 .067 & 1.603 .238 .372 & -1.103 .991 .305 \\
\hline
\end{tabular}

Sumber: Data Diolah, 2020

Working Capital to Total Assets ( $\left.\mathrm{X}_{1}\right)$

\begin{tabular}{|c|c|c|c|}
\hline Tahun & $\begin{array}{c}\text { Working Capital } \\
\text { (Rp) }\end{array}$ & $\begin{array}{c}\text { Total Assets } \\
(\mathbf{R p})\end{array}$ & $\begin{array}{c}\mathbf{X}_{\mathbf{1}} \\
\text { (Rasio) }\end{array}$ \\
\hline 2015 & 192.522 .261 & 2.883 .807 .269 & 0,067 \\
\hline 2016 & 537.875 .351 & 2.557 .262 .840 & 0,210 \\
\hline 2017 & -82.235 .630 & 2.010 .013 .010 & $-0,041$ \\
\hline 2018 & -1.103 .991 .305 & 1.269 .024 .960 & $-0,870$ \\
\hline
\end{tabular}

Sumber: Data Diolah, 2020

\section{Retained Earnings to Total Assets $\left(\mathrm{X}_{2}\right)$}

Rasio ini menunjukkan kemampuan perusahaan untuk menghasilkan laba ditahan dari total aktiva perusahaan. Rasio ini digunakan untuk mengukur profitabilitas kumulatif.

\section{Retained Earnings to Total Assets ( $\left.\mathrm{X}_{2}\right)$}

\begin{tabular}{|c|c|c|c|}
\hline Tahun & $\begin{array}{c}\text { Retained } \\
\text { Earnings } \\
(\mathbf{R p})\end{array}$ & $\begin{array}{c}\text { Total Assets } \\
\mathbf{( R p )}\end{array}$ & $\begin{array}{c}\mathbf{X}_{\mathbf{2}} \\
\text { (Rasio) }\end{array}$ \\
\hline 2015 & 381.773 .825 & 2.883 .807 .269 & 0,132 \\
\hline 2016 & 197.730 .446 & 2.557 .262 .840 & 0,077 \\
\hline 2017 & -297.745 .639 & 2.010 .013 .010 & $-0,148$ \\
\hline 2018 & -1.122 .411 .739 & 1.269 .024 .960 & $-0,884$ \\
\hline
\end{tabular}

Sumber: Data Diolah, 2020

\section{Earning Before Interests and Taxes to Total Assets $\left(\mathrm{X}_{3}\right)$}

Rasio ini menunjukkan kemampuan perusahaan untuk menghasilkan laba dari aktiva perusahaan sebelum pembayaran bunga dan pajak.

\section{Earning Before Interests and Taxes to Total Assets $\left(\mathrm{X}_{3}\right)$}

\begin{tabular}{|c|c|c|c|}
\hline Tahun & $\begin{array}{c}\text { EBIT } \\
\text { (Rp) }\end{array}$ & $\begin{array}{c}\text { Total Assets } \\
\text { (Rp) }\end{array}$ & $\begin{array}{c}\mathbf{X}_{3} \\
\text { (Rasio) }\end{array}$ \\
\hline 2015 & 239.909 .345 & 2.883 .807 .269 & 0,083 \\
\hline 2016 & -26.193 .815 & 2.557 .262 .840 & $-0,010$ \\
\hline 2017 & -382.739 .952 & 2.010 .013 .010 & $-0,190$ \\
\hline 2018 & -300.962 .518 & 1.269 .024 .960 & $-0,237$ \\
\hline
\end{tabular}

Sumber: Data Diolah, 2020

\section{Book Value of Equity to Book Value of Total Debt ( $\left.\mathrm{X}_{4}\right)$}

Rasio ini digunakan untuk mengukur kemampuan perusahaan membayar kewajibannya, baik jangka pendek maupun jangka panjang apabila perusahaan dibubarkan atau dilikuidasi 
Book Value of Equity to Book Value of Total Debt $\left(\mathrm{X}_{4}\right)$

\begin{tabular}{|c|c|c|c|}
\hline Tahun & $\begin{array}{c}\text { Book Value of } \\
\text { Equity (Rp) }\end{array}$ & $\begin{array}{c}\text { Total Debt } \\
\text { (Rp) }\end{array}$ & $\begin{array}{c}\mathbf{X}_{4} \\
\text { (Rasio) }\end{array}$ \\
\hline 2015 & 920.983 .904 & 1.962 .823 .365 & 0,469 \\
\hline 2016 & 736.712 .814 & 1.820 .550 .026 & 0,405 \\
\hline 2017 & 246.512 .696 & 1.763 .500 .314 & 0,140 \\
\hline 2018 & -584.587 .091 & 1.853 .612 .051 & $-0,315$ \\
\hline
\end{tabular}

Sumber: Data Diolah, 2020

Dari keempat rasio yang telah dihitung diatas, maka hasil analisis dari Z-score dapat dilihat pada tabel berikut ini:

Hasil Analisis Z-score

\begin{tabular}{|c|c|c|c|c|c|c|}
\hline Tahun & $\mathbf{X}_{\mathbf{1}}$ & $\mathbf{X}_{\mathbf{2}}$ & $\mathbf{X}_{\mathbf{3}}$ & $\mathbf{X}_{\mathbf{4}}$ & Z-score & $\begin{array}{c}\text { Hasil } \\
\text { Analisis }\end{array}$ \\
\hline 2015 & 0,067 & 0,132 & 0,083 & 0,469 & 1,920 & Grey Area \\
\hline 2016 & 0,210 & 0,077 & $-0,010$ & 0,405 & 1,987 & Grey Area \\
\hline 2017 & $-0,041$ & $-0,148$ & $-0,190$ & 0,140 & $-1,881$ & Bangkrut \\
\hline 2018 & $-0,870$ & $-0,884$ & $-0,237$ & $-0,315$ & $-10,512$ & Bangkrut \\
\hline
\end{tabular}

Sumber: Data Diolah, 2020.

Berdasarkan perhitungan Z-score original pada tabel 4.6 pada periode 2015 dan 2016 perusahaan PT Express Transindo Utama tbk menunjukkan hasil analisis Grey Area. Sedangkan pada periode 2017 dan 2018 perusahaan mengalami potensi kebangkrutan. Hal tersebut dapat dilihat dari hasil perhitungan analisis Z-score pada tahun 2015 dan 2016 kriteria Z-score berada diantara angka-angka cut off yaitu 1,1 dan 2,6. Dalam perhitungan Z-score diatas menunjukkan hasil yaitu pada tahun 2015 sebesar 1,92; pada tahun 2016 sebesar 1,987; pada tahun 2017 sebesar $(1,881)$; dan pada tahun 2018 sebesar $(10,512)$. Jadi dari perhitungan tersebut dapat disimpulkan bahwa pada tahun 2015 dan 2016 perusahaan tidak dalam keadaan sehat ataupun keadaan bangkrut. Tetapi pada tahun 2017 dan 2018 perusahaan mengalami potensi kebangkrutan.

\section{PEMBAHASAN}

Berdasarkan hasil analisis pada data perusahaan tahun 2015, 2016, 2017, dan tahun 2018 perusahaan mengalami kebangkrutan. Pada tahun 2015 perusahaan dalam beberapa indikator keuangan utama mengalami penurunan. Penurunan pada tahun 2015 ditunjukkan pada penurunan aset sebesar 4\% dari Rp2.884 miliar dari sebelumnya Rp3.011 miliar pada tahun 2014. Namun demikian, perusahaan mampu membukukan laba serta nilai pendapatan yang positif. Walaupun laba dan pendapatan perusahaan menunjukkan hasil positif atau tidak mengalami penurunan, oleh karena itu hasil analisis menggunakan Altman Z-score pada tahun 2015 menunjukkan bahwa perusahaan masuk dalam kategori grey area karena menunjukkan angka $1,1<\mathrm{Z}<2,6$ yaitu 1,92

Pada tahun 2016 perusahaan mengalami penurunan pada indikator pendapatan. Pendapatan perusahaan pada tahun 2016 dicatat sebesar Rp618 miliar, pendapatan tersebut menurun sebanyak 36\% jika dibandingkan dengan tahun 2015 yang dicatat sebesar Rp970 miliar. Perusahaan juga membukukan rugi bersih sebesar Rp184 miliar. Nilai aset perusahaan pada tahun 2016 mencapai Rp2.557 miliar, nilai ini menurun dibandingkan dengan tahun 2015 yang tercatat sebesar Rp2.883 miliar. Earnings Before Interest, Taxes, Depreciation and Amortization (EBITDA) atau pendapatan sebelum dikurangi pajak, bunga, depresiasi dan amortisasi pada tahun 2016 tercatat Rp238 miliar, menurun jika dibandingkan dengan tahun 2015 yang tercatat sebesar Rp514 miliar. Dapat disimpulkan pada tahun 2016, perusahaan mengalami penurunan kinerja 
keuangan akan tetapi hasil analisis menggunakan Altman Z-score menunjukkan bahwa perusahaan masuk dalam kategori grey area. Hasil analisis menunjukkan angka $1,1<\mathrm{Z}<$ 2,6 yaitu sebesar 1,987 .

Kinerja keuangan pada tahun 2017 juga mengalami penurunan pada indikator tertentu. Pada tahun 2017 pendapatan perusahaan mengalami penurunan dari sebesar Rp304,7 miliar dibandingkan dengan tahun 2016 sebesar Rp618 miliar, pendapatan perusahaan tersebut turun 50,7\%. Perusahaan juga membukukan rugi bersih sebesar Rp492,1 miliar. Nilai aset pada tahun 2017 mencapai Rp2.010 miliar, nilai ini menurun dibandingkan dengan tahun 2016 yang tercatat sebesar Rp2.557 miliar. Dilihat dari kinerja keuangan perusahaan pada tahun 2017 menurun dibandingkan dengan tahun 2016, hasil analisis menggunakan Altman Z-score pun membuat perusahaan masuk dalam kategori bangkrut karena angka $\mathrm{Z}<1,1$ yaitu sebesar $-1,881$.

Terakhir pada tahun 2018, kinerja keuangan perusahaan pun mengalami penurunan dibandingkan dengan tahun sebelumnya tahun 2017. Pendapatan turun sebesar 20,69\% yaitu sebesar Rp241,7 dibandingkan tahun 2017 sebesar Rp304,7 miliar. Pada tahun 2018 pun perusahaan masih membukukan rugi bersih sebesar Rp836,8 miliar. Nilai aset perusahaan pada tahun 2018 mencapai Rp1.269 miliar, nilai ini pun menurun dibandingkan dengan tahun 2017 yang tercatat sebesar Rp2.010 miliar. Penurunan kinerja keuangan juga masih terjadi pada tahun 2018, hasil analisis menggunakan Altman Z-score pun menunjukkan perusahaan masuk dalam kategori bangkrut karena angka $\mathrm{Z}<1,1$ yaitu sebesar $-10,512$.

Pembahasan diatas menunjukkan kinerja keuangan perusahan mengalami penurunan. Pada tahun 2015 dan 2016 perusahaan masuk dalam kategori grey area, yaitu posisi dimana perusahaan tidak dalam keadaan bangkrut ataupun keadaan sehat. Pada tahun 2017 dan 2018 berdasarkan hasil analisis Altman Z-score perusahaan terindikasi mengalami kebangkrutan. Dapat disimpulkan bahwa kebangkrutan perusahaan dapat terjadi karena perusahaan tidak mampu mengelola aset, modal, ataupun penjualannya untuk meningkatkan keuntungan perusahaan yang menjadi tujuan utama perusahaan. Oleh karena itu untuk memperbaiki kinerja keuangan perusahaan harus memperkecil hutang dan meningkatkan pendapatan perusahaan.

\section{KESIMPULAN}

Dari hasil penelitian dan analisis data yang menggunakan Model Altman Z-score untuk memprediksi kebangkrutan pada PT Expresss Transindo Utama (TAXI), tbk dapat disimpulkan bahwa Perusahaan PT Express Transindo Utama (TAXI), tbk pada tahun 2015 dan 2016 masuk dalam kategori grey area lalu pada tahun 2017 dan 2018 perusahaan mengalami kebangkrutan. Kebangkrutan perusahaan disebabkan oleh perusahaan yang tidak dapat memaksimalkan penjualan atau pendapatan, sedangkan biaya operasional perusahaan mengalami peningkatan yang menyebabkan kebangkrutan bagi perusahaan

Prediksi kebangkrutan perusahaan menggunakan Model Altman Z-score pada PT Express Transindo Utama (TAXI), tbk untuk tahun 2015 dan 2016 perusahaan berada dalam posisi tidak bangkrut dan juga tidak sehat yang terlihat dari hasil analisis Z-score yang berada diantara 1,1 dan 2,6 Untuk tahun 2017 dan 2018 perusahaan terindikasi mengalami kebangkrutan yang terlihat dari hasil analisis Z-score yang berada dibawah 1,1. Hal ini terjadi dikarenakan jumlah hutang lancar perusahaan yang melebihi aset lancar perusahaan, yang menyebabkan perusahaan tidak mampu membayar hutang lancar dengan aset lancar yang dimiliki perusahaan. Selain itu, pendapatan atau 
penjualan perusahaan yang lebih rendah dari biaya operasional yang dikeluarkan juga menjadi penyebab kebangkrutan perusahaan.

\section{REFERENSI}

Adhitama, Muh Luthfi. (2016). Analisis Laporan Keuangan dengan Menggunakan Metode Altman dalam Memprediksi Potensi Financial Distress Perusahaan Manufaktur yang Terdaftar di Jakarta Islamic Indeks (JII). Skripsi Fakultas Ekonomi dan Bisnis Islam. Universitas Islam Negeri Alauddin Makassar.

Alim, A. F. (2017). Analisis Prediksi Kebangkrutan dengan Model Altman Z-Score pada Perusahaan Makanan dan Minuman yang Terdaftar di Bursa Efek Indonesia. Jurnal Fakultas Ekonomi. Universitas Islam Indonesia.

Altman, E. I. (1968). Financial Ratios, Discriminant Analysis and The Prediction of Corporate Bankruptcy. Journal of Finance, 23(4), 589-609.

Baridwan, Z. (2013). Intermediate Accounting Edisi 8. Yogyakarta: BPFE.

Bursa Efek Indonesia. (2015). (2016). (2017). (2018). Laporan Keuangan. www.idx.co.id. Diakses tanggal 30 Januari 2020.

Fahmi, I. (2015). Analisis Laporan Keuangan. Bandung: Alfabeta.

Hery. (2015). Analisis Kinerja Manajemen. Jakarta: Grasindo.

Hanafi, Mamduh M dan Halim. (2016). Analisis Laporan Keuangan. Yogyakarta: UPP AMP YKPN

Hanafi, Mamduh M. (2014). Manajemen Keuangan Edisi 1. Yogyakarta: BPFE.

Harahap, Sofyan S. (2015). Analisis Kritis Atas Laporan Keuangan. Jakarta: PT Raja Grafindo Persada.

Ikatan Akuntan Indonesia. (2015). Standar Akuntansi Keuangan. Jakarta: Ikatan Akuntan Indonesia.

Ikatan Akuntan Indonesia. (2017). Standar Akuntansi Keuangan. Jakarta: Ikatan Akuntan Indonesia.

Kasmir. (2016). Analisis Laporan Keuangan. Jakarta: Rajawali Pers.

Kurniawati, L., \& Kholis, N. (2016). Analisis Model Prediksi Financial Distress pada Perusahaan Perbankan Syariah di Indonesia. Syariah Paper Accounting FEB UMS, 145153.

Munawir. (2010). Analisis Informasi Keuangan. Yogyakarta: Liberty

Nugroho, M. Iqbal Dwi. (2012). Analisis Prediksi Financial Distress dengan Menggunakan Model Altman Z-Score Modifikasi 1995. Skripsi Fakultas Ekonomika dan Bisnis. Universitas Diponegoro.

Oktarina, Eka. (2017). “Analisis Prediksi Kebangkrutan dengan Metode Altman Z-Score pada PT. BRI Syariah." Tugas Akhir Fakultas Ekonomi dan Bisnis Islam. Universitas Islam Negeri Raden Fatah Palembang.

Perusahaan Express Grup. (2015). (2016). (2017). (2018). Laporan Tahunan. www.expressgroup.co.id. Diakses Tanggal 31 Januari 2020.

Prihadi, T. (2011). Analisis Laporan Keuangan Teori Dan Aplikasi. Jakarta: PPM Manajemen.

Sujarweni, V.W. (2018) Metodologi Penelitian Bisnis Dan Ekonomi Pendekatan Kuantitatif. Yogyakarta: Pustaka Baru Press.

Tambunan, R. W., Dwiatmanto, \& Wi Endang N.P, M. G. (2015). Analisis Prediksi Kebangkrutan Perusahaan dengan Menggunakan Metode Altman (Z-Score) (Studi Pada Subsektor Rokok yang Listing dan Perusahaan Delisting di Bursa Efek Indonesia Tahun 2009 - 2013). Jurnal Administrasi Bisnis, 2(1), 1-11.

Undang-Undang Nomor 4 Tahun 1998 tentang Kepailitan. 